\title{
INDONESIA'S INTERFERENCE IN TRANSLATING TEXT INTO ENGLISH TEXT
}

\author{
${ }^{(1)}$ Etika Ariyani, ${ }^{(2)}$ Haris Mulyanto \\ (1) Lecturer of English Department University of Muhammadiyah Mataram \\ (2) Student's of English Department University of Muhammadiyah Mataram
}

\begin{abstract}
This research is aimed: (1) to reveal that interference of bahasa Indonesia interrupt when the students at the sixth semester of FKIP in Muhammadiyah University of Mataram translate the English narrative past tense text; (2) to know the kinds of factors interupted the students' in translating English narrative the text. The population of study were students in FKIP Muhammadiyah University of Mataram. They consist of three classes from class A to C. The number of population were 64 students so, the writer took only the 17 students to be sample, by using purposive sampling technique. The results of research showed that: (1) among 17 students in class A do some intereferences, they have less ability to construct the translation target text into the accuracy, acceptable and understandable/readable sentences by the reader. Moreover, there are two main Indonesian interference found by the researcher, they were morphological interference by misunderstand of using past tense sentences and sintactical interference by unstructural sentence in the target text, (2) The students' only could get the range from 4 score to 8 score, where 5 students get very poor, 4 students get poor, 2 students get fair, 3 students get fairly good, 3 students get good. The students' translation percentage for each standard such as accuracy is $16,5 \%$, acceptable is $10,11 \%$, readability is $5,47 \%$ and for total all of students' mean score is $51,9 \%$, where it took on poor score of translation (3) There are 4 factors made the students difficult to translate the target text, they were 1 . Disloyalty of the speakers and receiver 2 Insufficient of vocabulary in translating the source language into target language, 3 . The prestige of the source language and style, 4. Daily habits in the mother tongue influence target text, (4) The students' translations result are 6 students got score of 0-3 namely very low level, 6 students got score of 5,5-6,5, who categorized as the low level, 2 students got the range score of 6,6-7,5, who categorized "sufficient level", there are 3 students got this "high level" with the range score of 7,6-9,5, and no one getting the "highest level" score in the range of 9,6-10.
\end{abstract}

Key Word: Translation, Indonesian interference 


\section{INTRODUCTION}

Interference is the term which disturb the process of translating the foreign language that conducted by everyone who are learned in translating from a language to another language. Usually, research on the second language acquisition and language contact, refers to the language influenced by a non native speakers to natives speakers language by doing some mistakes, for example when it was translated from a language (source Language) to another language (Target Language) (Ellis, 1998: 51). In this case of interference, it would be easier resulted "the negative interference", which as synonym of the term wouldn't appropriate with target language. Recently, many researcher did the experiment about the interference and surprisingly, they have found the similar case as Weinreich did, again and again it resulted the same thing as Ellis did, they found the negative carries from the source language which do not sufficient where the connotation has bring negative translation from the source language (F1) and therefore increasingly tended to avoid it, preferring the term transfer instead to target language (Ellis, 1998: 51).

For example that found by Ellis, Cartford and Hornby stated in Winartu Kurningtias about "kualitas hasil penerjemahan kelompok dan individu" that the main explicit problem faced by Indonesian especially for students, were the accuracy, acceptability, readability of the translation target text. It was clearly to find how much the vocabulary they own in translating the text. The teacher who is teaching the English writing skill must be found it, when they translate the target text. The reason is translation of the words, meaning, types are different. It is quite difficult because when the translator found the accurate words to translate it, and yet it was related to the diction of the text, it would be different.

It indicated the urgent problems if we check out on the words as ",nasi" (Indonesia), Reis (Jerman), Rijst (Belanda), rice (Inggris) however it will be different on the sentences of "Nasi uduk sangat nikmat untuk sarapan" translated to Germany means "Es schmeckt gut den Reis mit der Cocosmilch gekocht wird mit gebratenen Zwiebel und einem Stück Omelett zum Frühstück essen". It so different with English that "It's delicious to have rice cooked in coconut milk with fried onion and slices of omelette for breakfast". The words that contained on the sentences are interpreted differently by the translator. To find the acceptability meaning is not easy and sometimes will be accurate to feel by us (Sylvia Rogi, 2009: 3-4).

In addition, the rest problems would be confused by the translator namely when the non native speaker of Indonesia doing their learning process, they would be used their commonly first language to do the direct translation for instance in the sentence of "apa saja contoh dari permasalahan yang anda alami?", and the correct translation is "what kind of problem do you have?". On the contrary, the students actually translate the sentence in form of result as their own translation such as "like what problem you have?". Another example explained the direct interference such as the example previous is in Ni Wayan Sadiyani thesis stated that "Direct interference can be found in transformation of passive and active voice to transfer into target language". It describes by the proof as follow:

Mereka sudah menjemput Tomo (Source Language)

They have meet Tomo (Target Language) 
Logically, both of those sentences are correct but when it touched to grammar field in the second language, it is false because it broken the rule play of grammar and it should be means "They had met Tomo" but commonly Indonesian will use their first language competence without pay any competence to translate into target language. Moreover in this case the second sentence translation is contained with the first language grammar rule which influenced the foreign language (source language) called" Negative Transfer/Translation", is stated by Weinrich namely; "Those instances of deviation from the norms of either language which occur in the speech of bilinguals as a result of their familiarity with more than one language, i.e. as a result of language contact, will be referred to as INTERFERENCE phenomena." (Weinreich, 1953:1)

The present study seeks to examine the interference of Indonesian In Translating of English which emphasizing of translation skill. This research conducted in Muhammadiyah University especially in English Department Students at $6^{\text {th }}$ semester. The selection of English Education students, starting from the reality that the English Learning process deviations are disturbing, especially on the rules that applied in English. The irregularities that occur when the students used English in the process of teaching and learning activities both verbally and in writing within and outside the classroom. However, in this study only focused on interference in translating of English which happened in written text of the students. Based on the issues that were outlined then, this study aims to know whether the students at the sixth semester made interferences in translating of English text and to identify the factors influenced the students in translating English Text.

\section{REVIEW OF RELATED LITERATURE}

\section{Concept of Interference}

Interference is the term first used in sociolinguistics by Weinreich (1970: 1) which says that the language is a form of interference irregularities in the use of the language of the norms that exist as a result of contact language or the introduction of more than one language and used in alternatively by the speakers. Furthermore, Weinreich continued that interferences phenomena in this day had removal the rule of the source language and misuse rules and norms of language. As explained in the background of the study, namely interference will disturb someone bilingual skill. For instance, in the sentence of "apa saja contoh dari permasalahan yang anda alami?", and the correct translation is "what kind of problem do you have?" but the translation commonly used by Indonesian people "like what the problem you have?",.

This is not valid as the source language but in this day moreover in speaking skill with less have grammar competence the translator doing this mistaken. Then, what had happened in the sample was the little part of linguistic interference in transferring target language, which is linguistic interference, consists of deviations or different world perceptions that result from the contact between L1, L2 or L1 and native language.

Furthermore, linguistic interference may result in positive or negative transfer, as explained above. Some researchers dedicate themselves to analyzing the separation of processing stages in lexical interference (e.g. Abel et al, 2008). In the others word, it could be happened when the translator doing the processing of translating the text which concern with auditory processing (Pallier et al, 2010, speech production (Hermans et al, 1998) and 
sentence comprehension (Schwartz et al, 2006) that caused the linguistic interference occurred. This statement is also has revealed by Benson (2002: 69)

\section{Interferences Level of Language}

According to Yusuf (1994:71) mentioned in Win Listyaningrum (2014: 305) explained that interference has four types namely, first, phonic interference which occurs when the speaker produce the errors meaning in speaking with the interlocutors, it influenced the dialect and the accents of the user. For example, when Sumbawa's people produced the sound "V" from the word "TV (television) they will be said "telepision".

Second is grammatical interference which takes place when an Indonesian English learner identifies morpheme or structure of his native into TL. Most of Indonesian will put Indonesian style of language when they make sentences. The sense is clearly appeared. Third, lexical interference. This kind of interference takes place in varied forms, e.g. words and phrases and fourth, semantic interference. It means that the term of interference can be happened whether it when someone is speaking or writing it will be disturb by those elements which caused of unawareness in speaking or writing. Such as explain by Weinrich (1970: 64)

There are many factors that contribute interference first, speaker bilingualism background. Bilingualism is the major factor of interference as the speaker is influenced by both of the source and the target language. Second, disloyalty to target language. Disloyalty to target language will cause negative attitude. This will lead to disobedience to target language structure and further force the bilingualist to put uncontrolled structure of his first language elements to output in practicing words utterances both oral and written. Students whose language background of TL is limited tend to put words in sentences or oral in structure and sense of first language.

Third, the limited vocabularies of TL mastered by a learner. Vocabularies of certain language mostly are about words of surroundings connected to life. Thus, a learner who is willing to master another language will meet new words differ from his native words and etc. Henceforth, interference may be called as a negative transfer. It may come from students' first language or mother tongue. Two aspects that can be potential problems are pronunciation and grammar. Bahasa Indonesia and English have different rule in those two aspects. Interference may happen in transferring the Indonesian language system to English.

\section{Interference in Translation}

Interference in translation will be happened if the translation text from its source language (hence forth SL) into the target language (henceforth TL) is processing. Concerning with the case, interferences are consist of different types of interferences in translation. These transfer may occur on all levels: phonology (foreign accent), syntax ("word-for-word"or "literal translation" (e.g. Munday (2008:19), lexis (such as false cognates), pragmatics (e.g. over-formality or under-formality) and morphology, which appears to be less affected than the others (Benson, 2002: 69).

\section{Types of Interference}

1. Interference in Phonology

Interference of phonology is the interference which happened when you pronounced the alphabet which similar soundly. 
The example is a Javanese who is mentioning some places which words are initiated with letters $/ \mathrm{b} /, / \mathrm{d} /, / \mathrm{g} /$, and $/ \mathrm{j} /$, as Bandung, Deli, Gombong, and Jambi. He unintentionally will pronounce /mBandung/, /nDeli/,/nJambi/, and /nGgombong/ (Chaer and Agustina, 2004). Surprisingly, "I myself feel funny when someone who is also a Javanese" asks me my origin and my answer is 'I am from nJaweng' (while the correct is 'I am from Jaweng').

2. Interference in Morphology

Morphological interference is regarded by many linguists as the most frequent one. It happened in the word formation by absorbing other derivational affixes. We often hear Indonesian words kepukul, ketabrak, kebesaran, kekecilan, kemahalan, sungguhan, bubaran, duaan, etc (Win Listyaningrum Arifin, 2011: 10) but the correct form of word formation should be "terpukul, tertabrak, terlalu besar, terlalu kecil, terlalu mahal, kesungguhan, berpisah (bubar), and berdua" (Chaer and Agustina, 2004). The previous data is clearly word formation process of morphological interference from root words that are added with certain affixes from indigenous language or other language (FL).

3. Interference in Sentence

This interference is a rare phenomenon. In fact, interference in sentence should be ignored as sentence pattern is a main character of certain language. Pay attention to these two sentences, "Rumahnya ayahnya Ali yang besar sendiri di kampung itu", and "Makanan itu telah dimakan oleh saya". The sentence form is indirectly influenced by native language understanding of someone that causes grammatical interference. Therefore the correct formation, i.e.: "Rumah ayah Ali yang paling besar di kampung ini", and "Makanan itu telah saya makan" (Chaer and Agustina, 2004). The language learner is trying to simplify the context by mixing sentence pattern between native language and target language.

4. Semantic Interference

According to recipient language, semantic interference is occurs when the acceptor language absorbs cultural insight of words as the origins from another language. This process is known as expansive. E.g. Indonesian takes words from Greece-Latin as demokrasi, politik, revolusi, and many more (Chaer and Agustina, 2004). Surprisingly, this borrowing process is natural and normal. English also takes many stems from other languages such as Latin for morpheme geo-, bio-, ology, -ghraphy, etc. The first process is through interference and then goes to integration by passing borrowing process.

Therefore, interference means by the experts is the negative translation that takes the normal or structural/correct form of normal translation in translating to the target language. For example, when someone produced the word "flu", it will be sound "plu". The incorrect one of phonology interference which disturbed the translation production of human part of body namely mouth. Then, interference could be happened in the forming of morpheme such as the additional of "kepukul", should be"terpukul", but those the commonly what happening in this day phenomena of interference. The next also from semantic interference which influence by the borrowing one of foreign language such from latin "democracy", be "demokrasi", in bahasa Indonesia. It really related then both of them also for the sentence however this case is not be the frequent case but this will lead us to the deviations of translation such as "Anak istri pak lurah itu cantik', so whether the word of "anak" whose beautiful or the word of "istri" whose beautiful. It means that the correct of the sentence is "Anak dari istrinya pak lurah itu cantik".

Then, the reason why this cases is still always appear because of the mother tongue of the translator, disobedience of the structure of the translation subject when the translator 
speak and write and the main cause of this matters is the limitation of vocabularies that has by the translator which cause of difficult to find the diction in translating the target text itself.

It is better for the translator if they want to translate the target text they have to acquire the knowledge in translating the target text into foreign language.

\section{Translation}

Translation has been known and done by many people so it attracted all linguists to expand more about the activity of translation. The reason which would raise the background of translation and it showed the theory of translation such Bell (1991: 6) who defined that translation is

"The replacement of representation of a text in one language by representation of an equivalent text in a second language"

The definition contains of translation as a changing or substitute from the source language $(\mathrm{BSu})$ into another texts $(\mathrm{BSa})$ by watching some grammar rules that produced in the translation's text. The similar definition was also stated by Cartford (on Hornby; 1998:15) as defined;

"Translation may be defined as follows; the replacement of textual material in one language (SL) by equivalent textual material in another language (TL).

Definition of translation above is emphasized that translation is not merely on the activity to transfer text of one's language to another but it has been of equal as the source language of bilingual in order the meaning has the appropriate with the source language.

However, the definition above is unspecific because it only emphasized on transferring the text merely whereas the cultural optional is not involve, while translation is communication tool between the writer and the reader who have the gaps of bilingual language.

According to the perception above that the function of translation as the connection, thus to achieve the position the translator should be able to transfer the message and also conditioned the message of the source language as contained as in the source language in order the reader can be get the point of the reader. The statement above are supported by Munday and Ian Mason who defined the translation as,

"an act of communication which attempts to relay, across cultural and linguistic boundaries, another act of communication which may have been intended for different purposes and different readers" (1997:1).

Therefore, it is clear that translation not only the activity to transfer the text of the source language toward the target language but also noticed for the cultural aspect and linguistic, it because of the existence of the different language and cultural between the writer and the reader.

\section{Types of Translation}

Every text has form and meaning. Therefore, the translation is divided into 2 parts: The first is according to the form and the second one is based on to the meaning. The translation that according to form is tried to follow the source language (Milred. L. Larson, 2001) and 
known as the literal translation. Then, the second one is used the meaning tried to deliver the meaning of the source text with the target language. This type of translation is called" idiomatic translation".

The interliner (Baris-berbaris) is the absolute literal translation. For the particular aims, it's necessary indeed the characteristic of source linguist text, for example, for the study of linguistic itself. The literal translation is benefit for the study nor the source language which is it can't be help so much the translator in translating the text who wants to know about the meaning of the source language. It seems the literal translation doesn't have meaning at all and almost doesn't have the communication value.

Both of translation above didn't deliver the meaning of the message, on the contrary the translation is not appropriate and the result should be appropriate as "Siapakah namamu?" an the other one is Apa saja jenis masalahmu? ".Commonly if the bilingual in one language family, it will be appropriate with the source language and understandable, it may be the form of grammatical is similar. Notwithstanding, the choosing of lexical made the translation sounds strange. Besides, to translate the inter liner translation, the absolute literal is functioned as equal language and changing the series of sources' grammatical toward the target language explicitly, but the lexical elements is translated literary, i.e:

ro ahombo ngusifu pamariboyandi

saya dia (perempuan)-oby. hati saya-mengikatnya (Lexical)

Saya mengikatnya di hati saya. (The literary translation was appropriate).

Furthermore, the idiomatic translation is the combination between literal translation and lexical translation which emphasized on how natural the translation as equal as the language with observe on the grammar rules and the optional of lexical elements. It related with free translation who doesn't pay attention on the grammar rules because it not easy to make appropriate source translation but this translation is only used if there's additional information who doesn't exist in the target language.

\section{Types of Good Translation}

As cleared previously that the good translation should be consist of text which refers to the source language (F1) or as equal as the first language or nonnative speakers language. It is explicitly that stated with the socio-linguistic competence of someone moreover as the translator he/she should be able to master the main competence in making the perfect result of translation, they are:

1. Linguistic Competence

2. Textual Competence

3. Domain/Subject Specific Competence

4. Cultural Competence

5. Research Competence

6. Transfer Competence

Those six competences are the requirements to complete result in translating. In the other words, by mastering these competences the translator will be made the good translation for the reader and it acceptable by the experts in translation. Therefore, behind of the competence the writer gives the small example of good translation as follows:

This case is set up from Papua's people language which has not connected with the source language but by attempts of the translator who lived around the destination object it can be transferred (from Deibler and Taylor, 1977:10-60) It sounds: 
"Decentralization of economic activity, planning and government spending, with emphasis on agricultural development, village industry, better internal trade, and more spending channeled through local and area bodies".

\section{METHOD}

This type of research is qualitative descriptive, it is intended that the results of research in the field of course be noted and recorded in accordance with the title, and then the data is accurately described, so that the reader can understand the language or the fans and became more apparent. This research is kind of case studies (Sutopo, 2001; 111-113).

The data extracted from a variety of sources and types of data that includes (1) informant or informants. The informant in the question is Muhammadiyah University Students at $6^{\text {th }}$ semester. (2) Events and Activities. Data interference of Indonesia's written text is taken when the informant is in the process of learning, especially when writing a discourse in English. The events in question are all activities undertaken students both inside and outside the teaching and learning activities. It deals with issues related to research types of data sources that can be used (Sutopo, 2002: 143).

In qualitative research, the source instrument is the researcher itself. Therefore, the research as the instrument should be "validated" as far as the research is ready to do in the next field of research. The validation of instrument consist of the understanding of qualitative method, mastering of the knowledge in the field of research, the preparing of the research entered the object of research, based on academic and logistically. The one to do the research is the researcher by self evaluation as far as in understanding the material, mastering of the theory, and the concept of the field be examined, and the mental preparing in the field of research

Then, the researcher applied the translation the written text, as the technique in collecting data.

a. Translation test

The translation test is a method of collecting data by giving some textual text in a form of short story test entitled "Tiga Anak Petani" (The Three Farmer Children)"from LKS Kartika Prima for Junior High School at IX class, then the students translate the Indonesian text into English. (Nababan, 2012: 39)

b. Content analysis

Content analysis is content of text that given to the $6^{\text {th }}$ semester students of English Department Program of FKIP UM-MATARAM. They got short story text with the level of their ability and the result of the test is analyzed and examined based on the Standard as follows;

Table 3.1 Standard in Analyze the text equivalence

\begin{tabular}{|lr|l|}
\hline $\begin{array}{l}\text { Standard of } \\
\text { Assessment }\end{array}$ & Description \\
\hline
\end{tabular}




\begin{tabular}{|l|l|l|l|}
\hline 1. Accuracy & $\begin{array}{l}3 \\
\text { (Matching) }\end{array}$ & $\begin{array}{l}2 \\
\text { (Lack of Matching) }\end{array}$ & $\begin{array}{l}1 \\
\text { (Not Matching) }\end{array}$ \\
\hline 2. Readability & 3 (Easy) & 2 (Sufficient) & 1 (Difficult) \\
\hline 3. Acceptability & 3 (Acceptable) & $\begin{array}{l}2 \\
\text { (Less Acceptable) }\end{array}$ & 1 (Unacceptable) \\
\hline
\end{tabular}

(Mangatur Nababan, et. al, 2012: 51)

Table 3.2 How to scoring the mean score of translation result of the students

\begin{tabular}{|c|c|c|c|c|c|}
\hline \multirow[t]{2}{*}{ No } & \multirow[t]{2}{*}{ Source Language } & \multirow[t]{2}{*}{ Target Language } & \multicolumn{3}{|l|}{ Scoring } \\
\hline & & & Accuracy & Acceptable & Readability \\
\hline 1. & $\begin{array}{l}\text { Hampir } 100 \% \text { manusia } \\
\text { setengah } \\
\text { Baya memerlukan kaca } \\
\text { mata. }\end{array}$ & $\begin{array}{l}\text { Almost } 100 \% \text { of } \\
\text { middle-aged } \\
\text { people } \\
\text { eyeglasses. }\end{array}$ & 3 & 3 & 3 \\
\hline 2. & $\begin{array}{l}\text { Mata dikatakan sebagai } \\
\text { "bagian } \\
\text { ukuran permukaan } \\
\text { tubuh yang } \\
\text { paling penting" } \\
\text { (Hanever, 1979, } \\
\text { h.1). }\end{array}$ & $\begin{array}{l}\text { The eye has been } \\
\text { referred to as "the } \\
\text { most important square } \\
\text { inch of the body } \\
\text { surface" } \\
\text { (Havener 1979, 1979, } \\
\text { p.1) }\end{array}$ & 2 & 2 & 2 \\
\hline 3. & $\begin{array}{l}\text { Dengan demikian, } \\
\text { perubahan } \\
\text { harus dilakukan dengan } \\
\text { menambah pencahayaan } \\
\text { di rumah, } \\
\text { perkantoran, restoran } \\
\text { dan pusat } \\
\text { geriatri (panti wreda). }\end{array}$ & $\begin{array}{l}\text { Therefore, changes } \\
\text { must be } \\
\text { made to improve } \\
\text { lighting in } \\
\text { homes, } \\
\text { restaurants, } \\
\text { and geriatric centres. }\end{array}$ & 1 & 3 & 3 \\
\hline & \multicolumn{2}{|l|}{ Jumlah } & 6 & 8 & 8 \\
\hline & \multicolumn{2}{|l|}{ Mean Score } & 2,0 & 2,67 & 2,67 \\
\hline
\end{tabular}




\section{FINDINGS AND DISCUSSION}

In this part, the writer wants to describe the analysis of the data obtained based on the research, conducted on June 2014 at English Education Program of Muhammadiyah University of Mataram. The writer obtained the data needed to be analyzed in this chapter. This analysis will answer the discussion towards finding out of investigation. Furthermore this research is conducted to answer the problem of investigation as formulated in the previous chapter, such as (1) Is the English student at the sixth semester of FKIP UM-MATARAM doing interference in translating text into English? and (2) What factors influenced the students in doing interference at the sixth semester Students of English Department Muhammadiyah University of Mataram in academic year 2014/2015

The writer intends to analyze the data by knowing the students' individual score in translating the translation text as shown as follows;

Table 01. Data of Students' Score in Translating Target Text

\begin{tabular}{|l|l|l|l|l|l|l|}
\hline \multirow{2}{*}{ No } & \multirow{2}{*}{ Name } & Score & $\begin{array}{l}\text { Total } \\
(\text { Mean } \\
\text { Score }\end{array}$ & Description \\
\cline { 3 - 6 } & & Accuracy & Acceptability & Readability & \\
\hline 1 & Eli Hermawati & 18 & 10 & 5 & 5,5 & Fair \\
\hline 2 & Indra Ayu Rusmini & 9 & 10 & 3 & 3,7 & Poor \\
\hline 3 & Amri Jaelani & 9 & 6 & 3 & 3 & Very Poor \\
\hline 4 & Juhari & 9 & 6 & 3 & 3 & Very Poor \\
\hline 5 & Hurniatun & 9 & 6 & 3 & 3 & Very Poor \\
\hline 6 & Farniati Lisani & 9 & 6 & 3 & 3 & Very Poor \\
\hline 7 & Hambali & 6 & 6 & 7 & 6,17 & Fairly Good \\
\hline 8 & Erniwati & 9 & 6 & 3 & 3 & Very Poor \\
\hline 9 & $\begin{array}{l}\text { Mukjizat Lailatul } \\
\text { Qodri }\end{array}$ & 21 & 16 & 9 & 8 & \multirow{2}{*}{ Good } \\
\hline 10 & $\begin{array}{l}\text { Dewi } \\
\text { Fajrin }\end{array}$ & 15 & 10 & 4 & 4,84 & \multirow{2}{*}{ Poor } \\
\hline 11 & Ipan Susanto & 18 & 12 & 8 & 6,34 & Fairly good \\
\hline 12 & Fitri Handayani & 18 & 10 & 7 & 5,34 & Poor \\
\hline 13 & Nuni Nuriani & 12 & 8 & 5 & 4,5 & Poor \\
\hline 14 & Deni Setiawan & 21 & 14 & 8 & 7,16 & Good \\
\hline 15 & Kurnia Harisanti & 18 & 12 & 8 & 6,34 & Fair \\
\hline 16 & Harmanyadi & 21 & 18 & 9 & 8 & Good \\
\hline 17 & Irwan Budiana & 24 & 16 & 5 & 7,5 & Fairly Good \\
\hline Total (F) & 237 & 172 & 93 & 88,39 & \\
\hline Percentage (P) & $16,5 \%$ & $10,11 \%$ & $5,47 \%$ & $51,9 \%$ & \\
\hline
\end{tabular}

After getting the result of the score test, the writer find out that among 17 students' translation result, a few of them make the interference by doing the commonly mistakes/intereference, it is Indonesian. Then, by calculated the data the researcher finds 
that the students' translation score cannot be reach in high score. In this case, the writer will employ to continue the analysis of students' percentage, whether the students' mean score is include of excellent or not in translating the target text, the writer used the analysis of the formula such follow:

a) Students' percentage of translation result:

$$
\begin{aligned}
& \mathrm{P}=\frac{\mathrm{F}}{\mathrm{N}} \times 100 \% \\
& \text { Where. } \\
& \mathrm{P}=\text { Percentage } \\
& \mathrm{F}=\text { Total of students' score for each standard } \\
& \mathrm{N}=\text { Total number of students }
\end{aligned}
$$

Notation: F. Accuracy = 237

F. Acceptability $=172$

F.Readability $=93$

$\mathrm{N} \quad=17$

b) P. Accuracy

$$
\begin{aligned}
\mathrm{P} & =\frac{\mathrm{F}}{\mathrm{N}} \times 100 \% \\
& =\frac{237}{17} \times 100 \% \\
& =16,5 \%
\end{aligned}
$$

c) P. Acceptability:

$$
\begin{aligned}
\mathrm{P} & =\frac{\mathrm{F}}{\mathrm{N}} \times 100 \% \\
& =\frac{172}{17} \times 100 \% \\
& =10,11 \%
\end{aligned}
$$

d) P. Readability:

$$
\begin{aligned}
\mathrm{P} & =\frac{\mathrm{F}}{\mathrm{N}} \times 100 \% \\
& =\frac{93}{17} \times 100 \% \\
& =5,47 \%
\end{aligned}
$$

e) P. Mean:

$$
\mathrm{P}=\frac{\mathrm{F}}{\mathrm{N}} \times 100 \%
$$




$$
\begin{aligned}
& =\frac{88,39}{17} \times 100 \% \\
& =51,9 \%
\end{aligned}
$$

Based on the percentation score above the researcher find out that most of translation calculation results above are less than of perfect, as stated in Heaton's scoring from 0-100, the writer found that the range 5 students get very poor, 4 student get poor, 2 students get fair, $\mathbf{3}$ students get fairly good, $\mathbf{3}$ students get good. In addition, the total students' percentation generally for accuracy is $16,5 \%$, acceptability is $10,11 \%$, readability is $\mathbf{5 , 4 7 \%}$ and for the total mean score is $\mathbf{5 1 , 9 \%}$, where it is include on poor score of translation .

If we focused back on Browns' category of translation percentage then, the researcher can conclude the percentage of translation results as shown above is classified as follows:

\begin{tabular}{|c|c|c|c|c|c|c|}
\hline $\begin{array}{l}\mathbf{N} \\
\mathbf{0}\end{array}$ & $\begin{array}{l}\text { Range } \\
\text { Score }\end{array}$ & $\begin{array}{l}\text { Qualification/ } \\
\text { Classification }\end{array}$ & Description & $\begin{array}{l}\text { Percentage } \\
\text { of } \\
\text { Accuracy }\end{array}$ & $\begin{array}{l}\text { Percentage o } \\
\text { Acceptability }\end{array}$ & $\begin{array}{l}\text { fPercentage } \\
\text { Readability }\end{array}$ \\
\hline 1 & $\begin{array}{l}(80 \%)- \\
(100 \%)\end{array}$ & $\begin{array}{l}\text { Excellent } \\
\text { (Very High) }\end{array}$ & $\begin{array}{l}\text { Translation is natural like it } \\
\text { is originally written in the } \\
\text { receptor language (TL) }\end{array}$ & 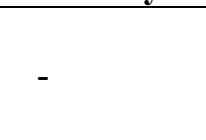 & - & - \\
\hline \multirow{2}{*}{2} & \multirow{2}{*}{$\begin{array}{l}(70 \%)- \\
(79 \%)\end{array}$} & $\begin{array}{l}\begin{array}{l}\text { Very good } \\
\text { (High) }\end{array} \\
\end{array}$ & \multirow{2}{*}{$\begin{array}{l}\text { Translation compatible } \\
\text { with the structure, meaning } \\
\text { and message in the receptor } \\
\text { language }\end{array}$} & \multirow{2}{*}{ - } & \multirow{2}{*}{ - } & \multirow{2}{*}{-} \\
\hline & & Good (High) & & & & \\
\hline 3 & $\begin{array}{l}(60 \%)- \\
(69 \%)\end{array}$ & $\begin{array}{l}\text { Fairly good } \\
\text { (Sufficient) }\end{array}$ & $\begin{array}{l}\text { Translation compatible } \\
\text { with structure and meaning } \\
\text { but message is not } \\
\text { compatible in the receptor } \\
\text { language }\end{array}$ & - & - & - \\
\hline \multirow[b]{2}{*}{4} & \multirow[b]{2}{*}{$\begin{array}{l}(50 \%)- \\
(59 \%)\end{array}$} & Fair (Low) & \multirow{2}{*}{$\begin{array}{l}\text { Translation suitable with } \\
\text { structure but message has } \\
\text { no meaning in the receptor } \\
\text { language }\end{array}$} & & \multirow[b]{2}{*}{ - } & \multirow[b]{2}{*}{ - } \\
\hline & & Poor (Low) & & & & \\
\hline 5 & $\begin{array}{l}(0 \%)- \\
(49 \%)\end{array}$ & $\begin{array}{l}\text { Very poor } \\
\text { (Very Low) }\end{array}$ & $\begin{array}{l}\text { Translation of students } \\
\text { translate each word in } \\
\text { sentence and ignored in } \\
\text { structure and meaning in } \\
\text { the receptor language }\end{array}$ & $16,5 \%$ & $10,11 \%$ & $5,47 \%$ \\
\hline
\end{tabular}

Table 02. Table Range Score of Qualification of The Study

(Brown, 2004:287) 
It can be inferred from the data above where the samples are 17 students at the sixth semester students in English Department of FKIP Muhammadiyah University of Mataram. They were given translation narrative written translation text in getting the translation mistakes/intereference term itself.

\section{CONCLUSION AND SUGGESTIONS}

1. Based on the finding that the researcher conclude that amount of 17 students at the sixth semester students always interrupted their translation work sheet text with interference when they translating the text, moreover in past narrative text. The interferences are morphological and sintatical interferences by deleting the past morpheme in the simple present tense forms and unstructural sentence. In addition, the writer found mostly that the students confused to translate the indonesia's text into English because of the form of the text which characterized as past tense. The students difficult to determine what form of tenses should they were using. Moreover, in the past narrative text, it is so much using suffix which made them difficult to translate the text are equivalence into the target language.

2. The students translations result are 6 students got score of 0-3 namely poor level, 6 students got score of 5,6-6,5 and 3,6-5,5 who categorized as the low level, 2 students got score of 6,6-7,5 who categorized "sufficient level", there are 3 students got this high level with the range score of 8,6-9,5 and 7,6-8,5 and no one getting the highest level score in the range of 9,6-10. In addition, the students have less ability to construct the text to be accurate, acceptable and readability in the range of good to very good in the result of translation percentage for each standard such as accuracy is $16,5 \%$, acceptable is $10,11 \%$, readability is $5,47 \%$ and for total all of students' mean score is $51,9 \%$ where it took on poor score of translation

3. The facts of students difficulties in translating the text during translating the text are 1 . Disloyalty of the speakers and receiver 2 insufficient vocabulary in translating the source language into target language 3 . The prestige of the source language and styli ${ }^{\wedge} n$ ily habits in the mother tongue influence target text

\section{REFERENCES}

Arikunto, Suharsimi. 2006. Prosedur Penelitian: Suatu Pendekatan Praktek. Jakarta: Rineka Cipta

Bell, R. T. 1991.Translation and translating: Theory and practice. London: Longman

Bhela, Baljit. 1999. Native language interference in learning a second language: Exploratory case studies of native language interference with target language usage. International Education Journal Vol 1, No 1, 1999.

Catford, J. C. 1965.A linguistic theory of translation. London: Oxford University Press.

Chomsky, N. 1965.Aspects of the theory of syntax. Cambridge, Mass.: MIT Press. 
Costa, B. Albareda and M. Santesteban. 2009. Assessing the presence of lexical competition across languages: Evidence from the Stroop task. New York: Cambridge University.

Deibler and Taylor. 1977. Words as "Bundles" of Meaning. Article of Translation in University of United Kingdom: Unpublished. http://a-salehi.co.uk/pages/LearningTools/Translation-Studies/Words-asbundles-of-meaning.pdf. Accessed on May 23th 2015 15; 44. P.M

J. C. Cartford. 1965. A Linguistic Theory of Translation. New York: Oxford University Press

Kunianingtyas, Winantu. 2008. A Thesis: Kualitas Hasil Penerjemahan Individu dan Penerjemahan Kelompok. Surakarta: Universitas Sebelas Maret

Mason, Ian. 2000. Text Parameters in Translation: Transitivity and Institutional Cultures. Translation Studies Reader. (2nd Edition). New York: Routledge

Munday. 2008. Introducing Translation Studies the Roudledge Companian to Translation studies. London and Newyork: Milton Park, Abingdon, Oxon OX14

Nababan., M. R. 2004. StrategiPenilaianKualitas. Jurnal Linguistic Bahasa, in Universitv of Surakarta,Vol. 2.No. 1.http://core.ac.uk/download/pdf/12351873.pdf. Acc $\quad$ in May $17^{\text {th }} 2015$ 19. 10 P.M

Nababan, P.W.J. 1984. Sosioliguistik: Suatu Pengantar. Jakarta: PT. Gramedia.

Newmark, L. 1966. How not to interfere with language learning. Language Learning: The Individual and the Process. International Journal of American Linguistics 40: 7778. Http://grammar.ucsd.edu

Sabricha Utama, Sari. 2013. A Thesis: Strategies In Translating Idiomatic Expressions of Phrasal Verb in Terence Blacker's Bilingual Novel "Ms Wiz Goes Live” Into "Ms Wiz Jadi Bintang Televisi by Mala Suhendra: Dian Nuswantoro University

Soewito. 1983. Sosiolinguistk: teori dan Problema. Surakarta: Kenary Offset

Sutopo, H.B. 2002. Metodologi Penelitian Kualitatif: Dasar Teori dan Terapannya dalam Penelitian. Surakarta: Sebelas Maret University Press

Van De Vijver.2004. Using Cognitive Interviewing for the Semantic Enhancement of MultiLingual Versions of Personality Questionnaires Short Title: Using Cognitive Interviewing for Test Adaptation: Journal of Linguistic Personality Assessment tin University of United Kingdom Vol.4.No.95.http://epubs.surrey.ac.uk/798033/1/Cognitive\%20interviewing\%20201 20808\%20Final\%20version\%20amdchanges\%20accepted.pdf. Accessed on May 24, 2015 at 15. 23 P.M 